\title{
Climatologists seek clear view of Asia's smog
}

David Cyranoski and Ichiko Fuyuno, Tokyo An international team gathered in South Korea this week to kick off a research project on Asia's persistent brown clouds of smog. The effort is the first long-term study into the effects of the haze on local and global climate.

The brown clouds frequently envelop vast portions of Asia. They wax and wane with the seasons but can be kilometres thick, causing respiratory disease and interrupting climate cycles.

Researchers on Project Atmospheric Brown Clouds, run by the United Nations Environment Programme (UNEP), are hoping that their study of the smog will help to spur preventative measures against the pollution. This could be especially important in the face of China's accelerating industrial boom.

The clouds consist of ash, acidic chemicals and carbon, which come from the burning of fossil fuels and wildfires. One of the most intensely polluted and most studied brown clouds, which hangs over the Indian Ocean, has recently been found to consist largely of the smoke from dried manure used for cooking (C. Venkataraman et al. Science 307, 1454-1456;2005).

Previous research has shown that the haze over the Indian Ocean blocks up to $15 \%$ of the Sun's radiation (S. K. Satheesh and V. Ramanathan Nature 405, 60-63; 2000). Such clouds are thought to cause the ground to cool and the atmosphere to warm, which can affect monsoons and other rainfall patterns. Particulate matter can also alter rain formation. But little is known about the details of how the clouds change over time, or how this alters the climate, says Veerabhadran

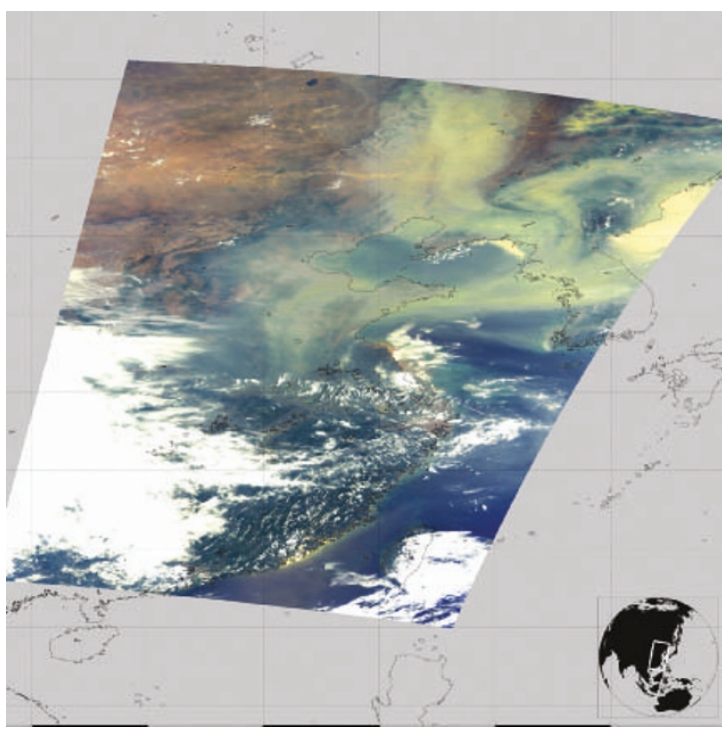

Foggy notion: Asia's hazy smog comprises fumes from forest fires (yellow) and pollution from populated areas (white).

composition of the clouds. Tens of smaller labs throughout the region will also contribute data.

The scientists involved say they are particularly concerned that the industrial boom and desertification currently going on in China are throwing ever more smog ingredients into the atmosphere. "East Asia might have more surprises than India - it is of a greater concern," says Ramanathan.

But the attempt to study China's impact on the clouds could become politically sensitive. Japanese scientists estimate that some $30 \%$ of the soot falling on their country comes from China, whereas Chinese researchers place the estimate as low as 5\%. "There is no consensus," says Yuanhang Zhang, an atmospheric chemist at Peking University who is representing China in the UNEP project.

Shiro Hatakeyama, a specialist in

Ramanathan, an atmospheric scientist at the Scripps Institution of Oceanography in La Jolla, California, who is involved with the UNEP project. "We need to watch the whole seasonal cycle for several years," he says. "There have been many theories about how this affects global climate. We have to observe it."

The UNEP project aims to follow the Asian clouds for at least five years; funding of US $\$ 10$ million has been secured for this period from the US National Oceanic and Atmospheric Administration and the National Science Foundation. The programme has two main observatories: one in the Maldives and one on the Korean island of Jeju. Each is stocked with more than 30 instruments that can measure incoming sunlight, temperature and the chemical atmospheric chemistry at the National Institute for Environmental Studies in Tsukuba, north of Tokyo, says that China has not provided sufficient information about its emissions to feed into models that predict the effects of the smog. "So far, China's efforts are not satisfactory," says Hatakeyama.

Zhang admits that there is a lack of data for most pollutants other than sulphur dioxide in China, making it hard to assess their contribution to the haze. Hatakeyama hopes that the project will put pressure on China to collect and provide more information.

That may already be happening. Zhang says that there are plans to set up about ten observatories in the country to contribute to the programme - a meeting is scheduled for April to work out the details.

\section{Biosafety law brings stem-cell research to Brazil}

Laura Nelson

Brazil has passed a landmark biosafety law that will legalize human embryonic stemcell research, and may open the way for the cultivation of genetically modified crops.

The move ends a period of uncertainty and frustration for Brazilian cell biologists by allowing them to use stem cells from frozen embryos left over from in vitro fertilization. It also establishes a clear process for the approval of genetically modified crops.

Although the law was vigorously opposed by church groups in Brazil, it was passed by the lower house of Congress on 2 March and is expected to be signed into law by President Luiz Inácio Lula da Silva in the next few weeks.
Brazilian stem-cell researchers welcomed the law - even though it forbids the cloning of stem cells for therapeutic use. "We are so happy," says Lygia Pereira, a cell biologist at the University of São Paulo.

A year ago, a preliminary version of the law passed by the lower house in Congress blocked the use of embryonic stem cells for research. But scientists and patient groups fought back to win the support of the Senate last October, and then that of the lower house this month.

"It is a huge step forward from the first draft that prohibited any kind of research with human embryos," says Pereira.

Previous biosafety regulations hadn't covered the use of stem cells, focusing instead on transgenic crops, banning their planting and commercialization. But genetically modified seed is being smuggled into Brazil, and the new law may allow for the crops' official approval.

Under the law, a body called the National Technical Commission on Biosafety (CTNBio) will advise on whether a genetically modified crop can be planted and commercialized. A council of government ministers will then have the final say.

Leila Oda, president of the National Biosafety Association, says that the law will facilitate research in agricultural biotechnology in Brazil. "Anyone wanting to do research simply applies to CTNBio," she says. 